\title{
Metastasis-Associated in Colon Cancer Protein 1
}

National Cancer Institute

\section{Source}

National Cancer Institute. Metastasis-Associated in Colon Cancer Protein 1. NCI

Thesaurus. Code C106605.

Metastasis-associated in colon cancer protein 1 (852 aa, $97 \mathrm{kDa}$ ) is encoded by the human MACC1 gene. This protein plays a role in both cell proliferation and cell motility. 